\title{
Alien Species and the Labyrinths Hindering Their Identification
}

\author{
福田 宏 \\ 岡山大学農学部水系保全学研究室． 7 700-8530 岡山市津島中 1-1-1
}

\section{Hiroshi FUKUDA}

Conservation of Aquatic Biodiversity, Faculty of Agriculture, Okayama University. Tsushima-naka 1-1-1, Okayama 7008530, Japan

\begin{abstract}
Numerous alien species have been reported in Japanese waters in recent years, but identifications of these species are difficult in most cases. In the Ariake Inland Sea, two new alien gastropods were found in 2000. One of them is Nassarius (Zeuxis) sinarus (Philippi, 1851) from China. This carnivorous species has recently increased explosively in number and has become a pest, eating fish caught in traps. This problem has spread rapidly over wide regions of the Ariake Inland Sea, with goby fisheries using traps in the central and western parts of Saga Prefecture suffering most. Unfortunately, this species was initially misidentified as the endangered species Mitrella martensi (Lischke, 1871). The other alien gastropod species is Stenothyra sp. from Korea. It is an undescribed species in spite of being an alien and had never before been reported from Korea. This case shows that alien species include not only ones that are abundant in their original distribution range, but also unrecognized ones. Several other taxonomic problems posed by alien species are reviewed. Most alien species in Japan have at first been misidentified and/or confused with other species. One of the most important measures to prevent such confusion is the adequate preparation of specimens. Because alien species often appear suddenly, we can not know their origin immediately. If enough specimens are preserved, exact identification may be made through subsequent study. In this connection, alpha-taxonomy will become ever more significant from now on. Comprehensive revisional works for many taxa will be needed in order to identify the alien species.
\end{abstract}

Key Words: alien species, alpha-taxonomy, Ariake Inland Sea, biodiversity, conservation, gastropods, identification, molluscs.

\section{はじめに一絶滅危惧種が漁業を加害？}

2001 年 11 月 26 日付けの朝日新聞西部本社版朝刊社会 面に, 「有明海 肉食性貝が大量発生 佐賀・熊本沖『かご 漁』など被害」という見出しの新聞記事が掲載された (Fig. 1). 記事本文によれば,「肉食性の巻貝が大量発生し，かご 漁などでかかった魚を食い荒らす被害が有明海で広がって いる」とされ，特に佐賀県の中西部を中心に「はぜかご漁」 への被害が最も大きかったという。記事には被害の一例む 挙げられており, 2001 年 11 月に鹿島市の漁業従事者が 70 個のかごを海底に仕掛け, 約 3 時間後に引き揚げたところ ほとんどの仕掛けたかごの内側も外側も「びっしりと」こ の貝に覆われ，かかった獲物むエサさえも「骨だけ」に

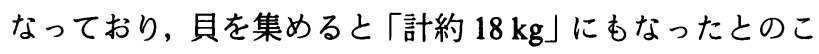
とである。

近年の有明海は, $7 \mathrm{~km}$ にわたる潮受け堤防によって干 潟を閉め切った諫早湾での大規模干拓なら゙の物理的改変

Received 8 Dec. 2003 Accepted 11 June 2004
や，化学物質による水質污染などによって急速に環境が悪 化していることはすでに何度む指摘されてきた（例えば佐 藤 2001).このような環境の悪化が生じると，必然的に在 来種の減少や消滅が生ずるとともに，污染や開発により擋 乱が著しい環境であっても定着しうる外来種（人為的移入 種）が増加し，さらに既存の生物群集に大きな影響を与え るというパターンが多く見られる（加藤 1999）こともよく 知られている事実である. 有明海の環境や生物相の変質が 深刻化している現在, 上記の「肉食性の巻貝」の異常発生 は,この海域における生態系の荒廃を端的に示すむのであ ろうし，これまでなかったような新たな漁業への被害が生 じた点でも重視すべき問題であるが，それと同時に，貝類 の分類を専門とする筆者にとってまず気になったのは，上 掲の新聞記事によって報じられた「肉食性の巻貝」の正体 は何か, ということであった.

この記事では, 問題の巻貝が「マルテンスマッムシガイ と思われる」とされている. また，記事の下部に付せられ た写真には, 問題の巻貝と「食べられて骨だけになったエ サのイワシ」, 及び 10 円玉が写っている。これを見るかぎ りこの巻貝は殻長に比して殼幅が大きく, 殼の輪郭は雫形 


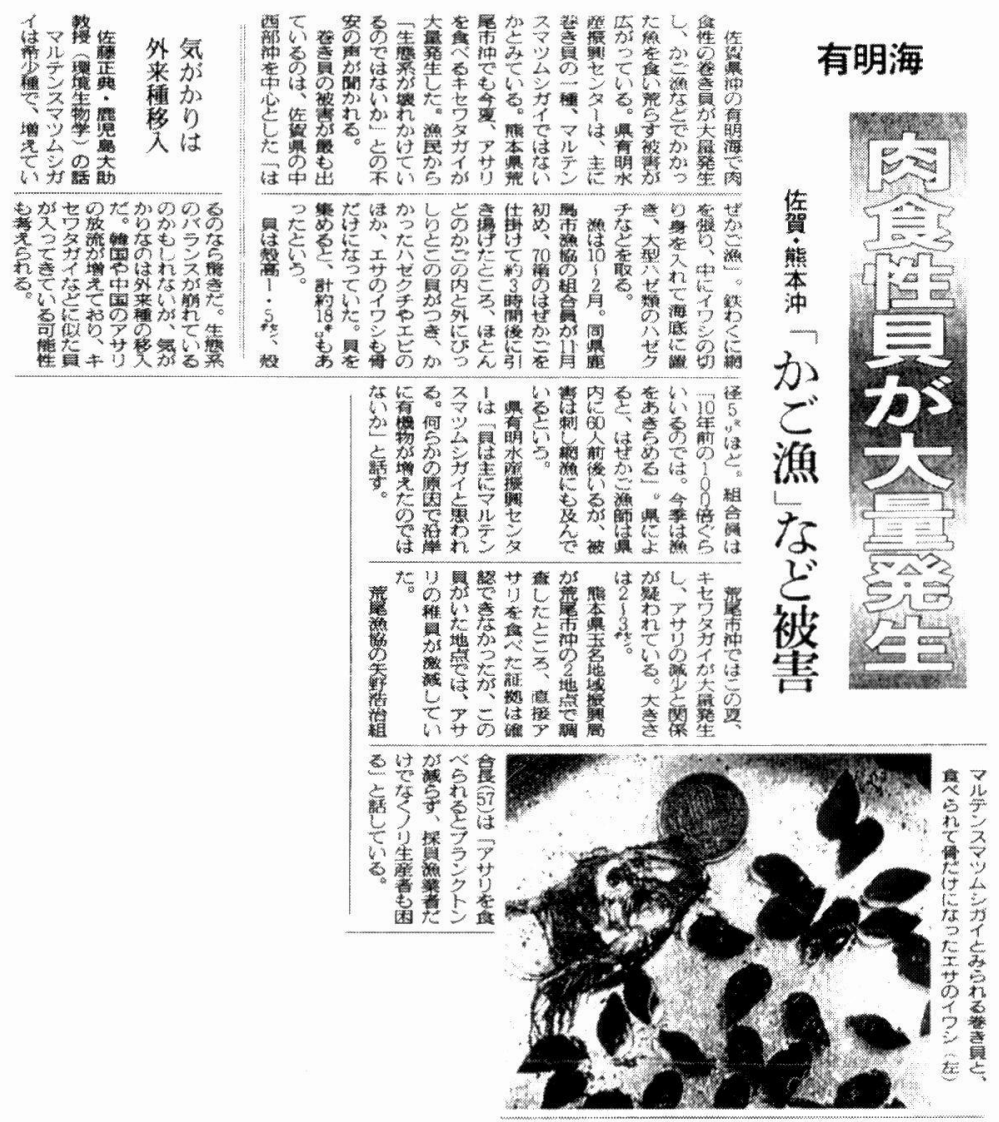

Fig. 1. Newspaper article from the Asahi Shinbun newspaper of November 26, 2001 entitled 'An upsurge of carnivorous snails in the Ariake Inland Sea. Off Saga and Kumamoto, baited trap fisheries are being damaged' (reproduced by courtesy of the Asahi Shinbun Co. Ltd.). In the article, the pest snail was identified as 'Mitrella martensi', but the accompanying photograph reveals it undoubtedly to be Nassarius (Zeuxis) sinarus, judged from the pyriform shell shape, wide aperture, and sculptures.

をなしている，殻口む広く種子形を呈していることが明ら かに見て取れる。ところが，実際のマルテンスマッムシ (Mitrella martensi (Lischke, 1871)) という種は, 殼長に比 べて殸幅が極端に小さく，細長い殻形をなすことが特徴で あり, 殼口む狭い. また, マルテンスマッムシが属する Columbellidae (=Pyrenidae) タモトガイ科（=フトコロガイ 科）の種は, 一部は小形貝類, 小形節足動物, 多毛類, 有 孔虫などを食すことが報告されているが，他の種では藻食 性と屯言われており (Wilson 1998), 記事のと抽り約 3 時 間」という短い間に,「八ゼクチやエビのほか，エサのイワ シむ骨だけに」してしまうことが可能とは考えにくい.さ らに強調されるべきは, マルテンスマッムシは和田ら (1996) によって「絶滅寸前」とされた種であり，「有明海な ごの大規模な内湾に少数が生き残っているだけである。 「東京湾や瀬戸内海では近年は古い死殻が見られるのみで, 屯はや絶滅かそれに近い状況にあると思われる」とされて いる点である、筆者自身（福田 2000）もかつて, 本種は「有 明海では今なお多産する」ものの, 他の産地では「壊滅状 態」と記したことがある。このような絶滅危惧種が，たと え有明海においては一定の個体数が保たれていたとして も，あるとき突然，漁業に深甚な被害を与えるほよ゙にまで
大発生するようなことが果たしてありうるだろうか. 確か に近年は, かつてマルテンスマッムシと同様に和田ら (1996)によって国内で「絶滅寸前」とされたEuspira fortunei (Reeve, 1855) サキグロタマッメタが，中国等から輸 入された食用二枚貝に混じって宮城県等に移入され，それ らの地域の在来種を食害する可能性む指摘されている（酒 井 2003; 大越 2003, 2004). マルテンスマッムシがサキグロ 夕マツメ夕同様に中国等加人為的に移入され，一時的に 有明海で増殖することは可能性としてはありえなくあな い.しかし，仮にそうだとしても，上記のような形態や食 性の点から, 問題の巻貝をマルテンスマッムシとするのは やはり䛊同定であると判断せざるをえない。

そこで，筆者なりに正しい同定を行抢うと試みた。上記 のような殻の特徵に加え, 多数の個体が魚なよ゙に群がって 短時間で食い尽くすという生態から, 問題の種は Nassariidaeオリイレヨフバイ科に属す種ではないかとまず考え た。また筆者らは, 上掲の新聞記事と前後して, やはり有 明海の福岡・佐賀県沿岸から, 記事の種と同種之思われる 種を多数採集していたので, それらの標本をむとに検討し ていたところ，その正体はあっけなく判明した。オリイレ ヨフバイ科の種については, Cernohorsky (1984) が，ほぼ 
全世界からこれまでに記載された種をまとめており，その 中にほとんどの夕クサのタイプ標本が図示されている。こ の文献に掲載された種とひとつひとつ照合していたとこ ろ，完全に合致する種が一つだけあった，中国の揚子江か ら記載されたNassarius (Zeuxis) sinarus (Philippi, 1851) が それである。この種と断定できる理由は，有明海の個体も $N$. (Z.) sinarus の夕イプ標本も, 殼の体首の途中から縦助 が弱まりほぼ平滑になるという他種に類例のない顕著な特 徵を共有しているからである。

この種は,これまで中国以外での記録例は皆無であっ た。 また有明海でも，2000 年以前の文献上に本種の記録は 一切現れておらず，それまでの筆者自身の調査結果や他の 研究者からの私信にも含まれていないため, 2000 年ごろを 境に突然出現したことは確実である．また一方で，環境擋 乱の結果在来種の減少がみられる有明海では, Meretrix lusoria (Röding, 1798) ハマグリ, Tapes (Ruditapes) philippinarum (A. Adams \& Reeve, 1850) アサリ, Sinonovacula constricta (Lamarck, 1818) アゲマキなど水産有用種む減少 しており，それらは中国や韓国なら゙から移植されている （菊池 2000; 佐藤 2000; 中井 2001). ここから， N. (Z.) sinarus は上記の水産有用種の移植に伴って大陸から人為 的に移入された外来種である可能性が考えられ，この種に カラムシロ（唐席）の和名を付して発表した (Tamaki et al. 2002).

\section{種の同定と保全}

カラムシロはそれ以降む有明海では多産し続け，また， その後瀬戸内海の岡山県倉敷市高梁川河口や浅口郡寄島町 であ生貝が確認されており（福田 2003），本種の侵入によ るさらなる生態系の擋乱や漁業被害が懸念されるところで あるが，ともかく絶滅危惧種マルテンスマッムシの「冤罪」 だけは晴らすことができた。むし，新聞記事通りにマルテ ンスマッムシと信じられたまま漁業被害への対策が講じら れたりしようあのなら，実は全く無関係でしかも絶滅の危 機にある在来種が目の敵にされ，積極的に駆除活動などが 行われる恐れがあったかむしれないのである．昨今は，生 態系や生物多様性の保全が頻繁に議論されるようになり, 実際に保全対策が現場で実施される例も多くなってきた。 それらの対策の中には，カラムシロのような「有害種の駆 逐」あ含まれるであろうし，その実施は必要なことである。 しかし，駆逐対象となる「有害」な種の同定は，つねに正 しいのかという問題提起をここでしておきたい.

有害種でなくとも，保全対策の現場では，つねに同定を 慎重に行う必要がある。例えば, 最近の筆者らの研究 (Suzukida \& Fukuda 2003) では，北海道から沖縄県までの 河口部汽水域に広く分布する「普通種」とされてきた $A s$ siminea japonica Martens, 1877 カワザンショウは，現時点 で判明しているだけであ実に 18 種が混在している。しか
もその中には，確かに広範囲に分布し，護岸などの環境擋 乱が生じても比較的個体群が維持される種もあれば，逆に たった 1 箇所の河口や干潟の，わずか 10 数 $\mathrm{m}$ の範囲だけ に固有な稀少種む複数含まれている（Suzukida \& Fukuda 2003; 鈴木田 2003).これらを従来の同定通りに「カワザン ショウ」としてしまえば, 例えばある場所の開発などが行 われる場合にアセスメント調查を実施したとしても，普通 種も稀少種も一様に, 「広く分布する普通種で, 環境擋乱に 強い」などと判断されてしまい，保全対策もなされないま ま絶滅に追い込まれる種が現れないとも限らないのであ る.

\section{外来種の同定}

しかし，在来種であるカワザンショウ類ですら上記のよ うに分類が著しく混乱していたのが現実であり，外来種の 同定はさらに困難である．ある分類群の分類に熟練した研 究者であっても, 多くの場合, 自分の住んでいる場所を中 心とした一定の地理的範囲に見られる種ならばほぼ完璧か つ短時間で同定できるが，これまで行ったことがない外国 にいきなり連れてゆかれて「さあすぐここの種を全部同定 しろ」と言われたならば，時間がかかるに違いない，科よ り上のレベルや，せめて属レベルの同定ならばともかく， 種レベルでの同定は困難を極めるであろう．外来種の同定 とは，それに似た作業である。その上，外来種は，多くの 場合突然現れるし，その時点ではどこからやって来たのか 全くわからず，本来の棲息環境む未知である，上掲の，力 ラムシロが比較的短期間で $N$. (Z.) sinarus に同定できたの は, むしろ異例中の異例であり, Cernohorsky (1984)のよ うな当該分類群の世界の種を網羅したモノグラフが存在し て初めて可能となったことである。そのような既存文献が ないグループの方が多いのであり，その場合は，全世界の 種に一つ一つあたってみるほかないのが現状である.

例えば，日本の広範囲に広がって定着したXenostrobus securis (Lamarck, 1819) コウロエンカワヒバリも，当初は, Limnoperna fortunei (Dunker, 1856) カワヒバリの別亜種 $L$. fortunei kikuchii Habe, 1981 として兵庫県西宮市から記載 され，その時は外来種とは認識されていなかった．実はコ ウロエンカワヒバリはカワヒバリとは同属ですらなく, オーストラリア周辺原産の X. securis であると Kimura et al. (1999) によって発表されるまで, 18 年が経過している. 同様に日本各地に定着したMytilus galloprovincialis Lamarck, 1819 ムラサキイガイも，長らくM. edulis Linnaeus, 1758 とされていたが，桑原 (1993) によって現在の同定に 落ち着くまで数十年を要している (奥谷 1996)。北米原産 の Crepidula onyx Sowerby I, 1824 シマメノゥフネガイも, 当初は C. fornicata (Linnaeus, 1758) ネコゼフネガイと誤っ て同定されていた（間瀬 1971; 波部 1972）.

このような外来種の同定を巡る混乱の歴史は枚挙にいと 
まがない、海産種のみならず陸産・淡水産貝類の外来種む 同様であり，たとえば現在全国的に人家の庭などに極めて 普通にみられるチャコウラナメクジす, 従来 Lehmannia marginata (Müller, 1774) であるとされてきたが, L. marginata は「自然度の高いビオトープにのみ見られる」「樹上 性」の種であり, 日本に移入された種は L. valentiana (Müller, 1774) であるとされたのは近年の狩野・後藤 (1996), 村山ら (1996), Kanô et al. (2001) などの報告まで待たねば ならなかった。また，「ジャンボタニシ」の俗称で広く知ら れ, 農作物への食害が報告されているPomacea canaliculata (Lamarck, 1819) スクミリンゴガイも, 当初は $P$. insularis (d’Orbigny, 1839) ラプラタリンゴガイと誤同定（波部 1986）されていたのである.

\section{外来種で未記載種？}

さらに，近年のように外来種の移入が頻繁になされるよ うになると，原産地ですら認識されていない種が運ばれて くる可能性がある。通常, 外国にまで広がるような外来種 は, 人為的に運ばれる確率の点から考えれば, 原産地でむ 多産する普通種（よく知られた種）であることが多いと考 えがちだが，実際には必ずしもそうではない。

カラムシロとほぼ同時期に有明海に現れた種に Stenoth$y r a \mathrm{sp}$. トライミズゴマッボがある。この種むカラムシロと 同様, 2000 年以前の文献には記録がないため, 外来種の可 能性が考えられたが, 偶然にも筆者らの研究中に, 韓国全 羅南道から形態的に一致する個体が見出された. 上述の上 おり, 有明海には韓国からもアサリ等の移植が行われてい るため, それに伴ってトライミズゴマッボあ韓国から運ば れてきた可能性があると判断し，報告した（福田ら 2002; Tamaki et al. 2002). ところが, 本種が属す Stenothyridae ミズゴマッボ科の分類学的研究は, 世界のどの地域でも著 しく遅れているか，または皆無である (Ponder \& De Keyzer 1998). 韓国においても同様であり，トライミズゴマッ ボも実際に韓国に分布しているにもかかわらず，その記録 はこれまで皆無である。このため, 本種は有明海では極め て多産しているにあかか⿰力らず，未記載種である可能性が 大きい.したがって本種は,「外来種で未記載種」という驚 くべき存在である。同様の例を他の動物門に求めると, 扁 形動物門渦虫綱の Bipalium nobile Kawakatsu \& Makino, 1982 オオミスジコウガイビルがある。本種は 1982 年に新 種記載された当時は東京周辺のみから知られていたもの の,「東南アジア原産 (中国南部?) の外来種」で, 「植木 鉢などに紛机込んだ分裂片が再生して増えるので, 今後む 分布圈が拡大するであろう」(川勝 1999）之考えられてい る.このように, 本来の分布域ではない場所で初めて発 見・認識される種は, さまざまな分類群において, 今後増 えてゆく可能性がある.

貝類に目を戻すと，さらに類似した例に Melanochlamys sp. ヤミヨキセワタがある.この種は和田ら (1996) によっ て千葉県木更津市小樻川河口や愛知県汐川干潟から初めて 報告された Aglajidaeカノコキセワ夕科の種で, 従来日本 から報告されたこの科のいずれの種にも合致しないむの の，「潮間帯という人目につきやすい場所に生息するにも 関わらず従来報告されたことがなく, かつ, 東京湾のよう な開発の進んだ場所に見られることを考えると，近年に なって外国から移入された可能性あある」とされている (和田ら 1996)。 その後本種は, 千葉県江戸川放水路, 宮城 県蒲生干潟, 山口県山口市長浜 (秋穂湾) からも産出が確 認された (福田未発表)。これらの産地のうち秋穂湾は, 極 めて自然環境の保存度が高く, 他の海域で絶滅または絶滅 寸前に追い込まれたベントスが今なお豊富に棲息し，外来 種が少ない場所として知られており（加藤 1999; 福田 2001), 和田ら (1996) が外来種である可能性の根拠として 挙げた「開発の進んだ場所に見られる」という点と矛盾す ることになるため, 本種が外来種であるのか, それともこ れまで見落とされてきた在来種であるのか，いまだに明確 に判断することができない，また，本種は当初和田ら (1996)によって「Aglaja? sp.」として報告されたが，その後 Melanochlamys Cheeseman, 1881 の一員であることが判明 した (佐々木 私信)。しかしこの属す詳細な検討はなされ ておらず，日本で見られる種に対して正確な種名の同定を 行うためには, 全世界のこの属の再検討を並行して行わざ るをえず, その上で初めて, 外来種なのか在来種なのか, 既記載種なのか未記載種なのかを明らかにするほかないよ うに思わ机る。

\section{おわりに一今求められているものは？}

現在の自然環境は, 開発や污染などに伴う擋乱ととあ に, 外来種の跳梁跋扈によって著しい混乱にある。 それと ともに, 生物の分類にも新たな混乱が生じている。 そして, そ机ら分類の混乱は, さらに保全対策の現場における混乱 をもたらし, 自然環境・生態系・生物多様性を保全し擋乱 から救うどころか，さらに悪影響を与える恐れもないとは いえない. いずれにせよ, 分類学（特に, 種レベルの同定 を行うアルファ分類学）の重要性が, 従来はなかったよう な形で増してきていることは疑いがない，外来種による生 態系への悪影響が今後ますます増大するおそれすある現状 では, その迅速かつ適確な対応のためにも, これまで以上 に分類学的知識を充実させることが必要之思わ机る。具体 的には次の二つの方向性が考えられる.

第一に, いつ, どこで, どんな種が, どのように産出し たかという基礎デー夕を，今まで以上に充実させるという ことである. 外来種の席捲によって在来の生物相がどのよ うな顔触れだったのかわからなくなるほど混乱してしまう 前に, 本来の生物相を把握しておくことが必要であろう. これは甚だ単純で簡単な作業のように思われるかもしれな 
いし，確かに分類学者でなくとも，例えば生態学・応用生 物学・教育関係等に従事する人々, アマチュア同好者など さまざまな立場の人々に等しく可能な「簡単な」ことであ るが, むしろ目下の急務である。，その際，文字や写真等に よる記録だけでなく，標本を作成して保管し，後世へ確害 に伝えることこそ重要であると強調しておきたい，標本は 産出の最む直接的な証拠というだけでなく，正確な同定の ために不可欠だからである. 証拠標本なしに種名だけを記 録に残してしまうと，その同定が疑わしくともただ盲目的 に信じるほかない（ということは，実は科学的な記録とし て意味がない）が，標本を残しておけばその同定が正し かったかどうかがあとで何度であ追試可能である。この意 味では，自前の限られた知識だけに基づいてただちに正し い同定結果を求めるという性急さ（これが往々にして誤同 定を招く）よりも，種名不詳のままでもともかく標本とそ れに伴うデータだけはきちんと残そうとする方が，むしろ 正確な同定への早道かもしれない，分類学者とそれ以外の 分野の人々が交流を深め, 標本を介して情報交換が活発化 すれば，かつて生じたような外来種の同定の混乱や紆余曲 折あ軽減できる可能性がある。

次に, 分類学者サイドとしては, 個々の種についての記 載を積み上げてゆくこととともに, 属や科など一定の高次 分類群に属するすべての種を網羅する再検討の仕事をさら に推進してゆく必要があるだろう。そのようなモノグラフ が，ひとつでも多くの分類群で作成されてゆけば，突然ど こからともなく出現したかのように見える外来種の同定に あ，大いなる援けとなるはずである．海外のフィールドで 仕事をすることが比較的容易になった近年は，国外でサン プルを自ら採集して検討することや，他国の博物館等の所 蔵標本の検討, 他国研究者との交流も頻繁に行われるよう になってきた。 あはや，どの国の分類学者む，各自が専門 とする分類群の世界中の種を等しく同定できることが要求 される時代が訪れつつあるように思われる.

筆者が最近継続して共同研究を行っているオーストラリ ア博物館 (Australian Museum) の軟体動物学研究室の主席 研究者である Winston F. Ponder 博士は, 上記のような世 界中の種のモノグラフを多数の科や属についてまとめあ げ, 軟体動物分類学に極めて大きな貢献をなしてきたが, その彼の研究室では現在も精力的な標本収集とそのデー夕 ベース化に余念がない. 同館が設立された 1827 年以来, 現 在までに収集された約 43 万ロットを超える貝類の標本を データベース化し，その産地・採集年月のデー夕をもとに 詳細な分布地図とその通時的変化がただちに開示できるよ うなシステムを構築している（43万ロットという標本数が いかに途方むないものであるかは，国立科学博物館の登録 済貝類標本が約 75,000ロット，また，オーストラリア博物 館に做って 2002 年 7 月から標本登録を開始した筆者の研 究室で約 9,000ロットであることを考えれば容易にご理解 (けただけると思う)。特に自国オーストラリアに関しては,
Ponder 博士自身がこれまでの所蔵標本データから作成し た分布地図を見ては，「この地方はまだちょっとサンプル が少ないな」等と言って当該地方へ採集へ出かけたりして いる．外部から同定依頼等のために送られてきた標本も， すべて登録し保存する．そのようにして蓄積したデータ は，例えば地理情報システム (GIS) を援用した多次元的な 生物多様性評価に用いることも可能であり (Ponder 1999; Ponder et al. 2001), あち万ん外来種の出現時期, 伝播, 分 布拡大, 棲息環境の嗜好, 消滅要因などの検討に関しても 威力を発揮するであろうことは疑いがない。ここに筆者 は, 外来種に代表されるような生物多様性保全の問題に対 し，分類学がいかに貢献しうるかという問いへの一つの明 確な回答があるように思う。Ponder 博士が中心運営メン バーのひとりとなっているオーストラレイシア軟体動物学 会 (Malacological Society of Australasia) の「最重要課題の ひとつ (one of the society's most important goals)」が, 「オーストラレイシアの生物相の保全 (the preservation and conservation of the fauna of Australasia)」とされているこ と(同学会ホームページ, http://www.amonline.net.au/ invertebrates $/ \mathrm{mal} / \mathrm{malsoc} /$ ethics $1 . \mathrm{htm})$ は偶然ではなかろ j.

謝 辞：原稿に関し詳細かつ懇切丁寧な助言を睗った本特集ゲ スト編集者岩崎敬二博士，本誌編集長大越和加博士，ならびに 2 名の匿名査読者に厚く御礼申し上げる.また，ヤミヨキセワタの 属の所属についてご教示いただいた佐々木哲朗氏 (東京海洋大学) に深謝する.

\section{引用文献}

Cernohorsky, W. 1984. Systematics of the family Nassariidae (Mollusca: Gastropoda). Bulletin of the Auckland Institute and $\mathrm{Mu}$ seum, 14: 1-356.

福田 宏 2000. 巻貝類 I一総論. 佐藤止典(編), 有明海の生きも のたち, 海游舎, 東京, pp. 100-137.

福田 宏 2001. 内湾の貝類「最後の楽園」周防灘一そして私たち がなすべきこと.日本ベントス学会誌，56: 33-41.

福田 宏 2003. 西日本における貝類の移入. 日本ベントス学会自 然環境保全委員会, 企画シンポジゥム「移入海産ベントスの生 息状況之環境的課題」報告, 日本ベントス学会誌, 58: 99-100.

福田 宏・溝口幸一郎・鈴木田亘平・馬堀望美 2002. 佐賀県太 良町田古里川河口の貝類相一2. 追加種. 佐賀自然史研究, 8: 4755.

波部忠重 1972. シマメノウフネガイとネコゼフネガイ。ちりぼた ん, 7: 49-50.

波部忠重 1986. ジャンボタニシの学名と和名. ちりぼたん，17 27-28.

狩野泰則・後藤好正 1996. 横浜市の陸産貝類. 神奈川自然保全研 究会報告書, 14: 43-106.

Kanô, Y., H. Fukuda, H. Yoshizaki, M. Saitô, K. Hosaka, T. Sugimura, Y.F. Itô, H. Fujiwara, Y. Nakamura, K. Mashino, K. Itô, K. Tone, T. Fukuda, T. Mitoki, H. Yamashita, S. Hori, K. Hori and H. Hori 2001. Distribution and seasonal maturation of the alien slug Lehmannia valentiana (Gastropoda: Pulmonata: Limacidae) in Yamaguchi Prefecture, Japan. The Yuriyagai, 8: 1- 
13.

加藤 真 1999. 日本の渚一失われゆく海辺の自然一, 岩波書店, 東京, $220 \mathrm{pp}$.

川勝正治 1999. ウズムシ綱．青木淳一(編), 日本産土畩動物一分 類のための図解検索, 東海大学出版会, 東京, pp. 3-8.

料池泰二 2000, 干潟浅海系の保全の意義. 佐藤正典(編), 有明海 の生きものたち, 海游舎, 東京, pp. 306-317.

Kimura, T., M. Tabe and Y. Shikano 1999. Limnoperna fortunei kikuchii Habe, 1981 (Bivalvia: Mytilidae) is a synonym of Xenostrobus securis (Lamarck, 1819): Introduction into Japan from Australia and/or New Zealand. Venus, 58: 101-117.

桑原康裕 1993. ムラサキイガイの正体. 北水試だより，21:14-18.

間瀬欣弥 1971. 相模のネコゼフネガイは「シマメ/ウフネガイ」 が妥当。ちりぼたん，6: 155 .

村山均・滝沢則之・佐藤 修・箕輪一博 1996. 柏崎市立博物 館所蔵江村重雄貝類標本目録. 柏崎市立博物館, 新潟.

中井克樹 2001. 貝類の世界で起きている異変. 川道美枝子・岩梘 邦男・堂本暁子(編)，移入・外来・侵入種 生物多様性を妿加 すむの, 築地書館, 東京, pp. 156-161.

大越健嗣 2003. サキグロタマッメタ一絶滅危惧種は食害生物。う みうし通信，39: 2-4.

大越健嗣 2004. 輸入アサリに混入して移入する生物一食害生物 サキグロタマッメ夕と非意図的移入種. 日本ベントス学会誌, 59: $74-82$.

奥谷喬司 1996. 日本のムラサキイガイ。ちりぼたん，27: 10-11.

Ponder, W. F. 1999. Using museum collection data to assist in biodiversity assessment. In The Other 99\%. The Conservation and Biodiversity of Invertebrates, Ponder, W. F. and D. Lunney (eds.), The Royal Zoological Society of New South Wales, Mosman, pp. 253-256.

Ponder, W. F., G. A. Carter, P. Flemons and R. R. Chapman 2001.
Evaluation of museum collection data for use in biodiversity assessment. Conservation Biology, 15: 648-657.

Ponder, W. F. and R. G. De Keyzer 1998. Superfamily Rissooidea. In Mollusca: The Southern Synthesis. Fauna of Australia, 5, Beesley, P. L., G. J. B. Ross and A. Wells (eds.), CSIRO Publishing, Melbourne, pp. 745-766.

酒井敬一 2000. 万石浦アサリ漁場におけるサキグロタマッメ夕 ガイの食害について。宮城県水産研究センター研究報告, 16 109-111.

佐藤正典 2001. 有明海の重要性一危機に瀕した干潟生物の最後 の砦一、日本ベントス学会誌，56: 55-57.

佐藤慎一 2000. 二枚貝類一特に諫早湾について. 佐藤正典 (編), 有明海の生きむのたち, 海游舎, 東京, pp. 150-183.

鈴木田亘平 2003. 従来「カワザンショウ」とされてきた種の再検 討一中津産 1 新種を含めて. 山口貝類研究談話会ニュースレ 夕-, 3: 6 .

Suzukida, K. and H. Fukuda 2003. Systematics and conservation of the cryptic species comprising 'Assiminea japonica' (Mollusca: Gastropoda: Rissooidea). Records of the South Australian Museum Monograph Series, 7: 303-309.

Tamaki, A., N. Mahori, T. Ishibashi and H. Fukuda 2002. Invasion of two marine alien gastropods Stenothyra sp. and Nassarius (Zeuxis) sinarus (Caenogastropoda) into the Ariake Inland Sea, Kyûshû, Japan. The Yuriyagai, 8: 63-81.

和田恵次・西平守孝・風呂田利夫 ・ 野島 哲 - 山西良平・西川輝 昭 - 五嶋聖治 ・鈴木孝男 - 加藤 真 ・島村賢正・福田 宏 1996. 日本に打ける干潟海岸とそこに棲息する底生生物の現 状. WWF Japan Science Report, 3: 1-182.

Wilson, B. 1998. Family Columbellidae. In Mollusca: The Southern Synthesis. Fauna of Australia, 5, Beesley, P. L., G. J. B. Ross and A. Wells (eds.), CSIRO Publishing, Melbourne, pp. 827-829. 